\title{
Accounting Information System as a Strategic Decision Making Tool in Banking Sector: Evidence from Bangladesh
}

\author{
Khondoker Ziaur Rahman \\ Lecturer, Department of Accounting, American International University-Bangladesh (AIUB), Dhaka-1213, BANGLADESH \\ E-mail for correspondence: ziaur.ron@gmail.com
}

\begin{abstract}
The core of any organization is accounting information, through which organizations become able to understand the financial situation of the business and they uses this accounting information from integration system as a basis for making strategic decisions. Since premeditated decisions have long term effect on the business and therefore it is important to analyze information from accounting information system for making long-term planned decisions. This study aiming to find out the impact of accounting information system as a strategic decision making tool focusing on the banking sector of Bangladesh. After conducting a questionnaire survey among 40 different private and public banks from Bangladesh, result shows that out of total respondent $72.5 \%$ are using this tool frequently on their Bank. I believe that this study will be able to find out importance of accounting information system as a strategic decision making tool in banks from developing countries. And this study will be helpful for the other developing countries banks if they are planning for implementing accounting information system as a decision making tool.
\end{abstract}

Keywords: Accounting, Information System, Strategic decision, Developing country, Bangladesh JEL Classification Code: M 41

\section{INTRODUCTION}

Accounting information is a part of day-to-day life and necessary to understand the accuracy of financial situation of any organization. It is also used as the basis for making business related decisions. Since planned decisions have a long-term effect on the business, therefore it is important to analyze accounting information for producing a better strategic assessment. Normally top management takes this kind of long-term planned decisions and allocates company's core assets to achieve that goal (Eugenia1 and Tiberius, 2013). Strategic decisions are among the most distinctive results in an organization, and company uses these for determining the goals and direction for long-term company development. Top management is involved in these sorts of decisions. A wrong strategic decision has far-reaching and has a negative effects on the company. This ultimately puts a lot of responsibility on the shoulders of the strategic decision maker (Trimisiu Tunji, 2012).

In this study, I have selected four strategic decision making areas such as basic, human resource management, longterm investment and Marketing. The strategic decision making for human resource department depends on the area of hiring, training and promotions. For developing new product or determining the sales commission, a sales manager can take help from accounting information.
Accounting information also helps to take long-term investment decisions by giving the proper view of present condition. However, top management needs accounting information in every step to take any sorts of strategic decisions but no significant study conducted on the importance of accounting information in strategic decisions making in banking sector, Bangladesh. Therefore, this study was conducted to estimate the significance of accounting information in strategic decision-making in banking segment, Bangladesh.

Accordingly, this research has been prepared to appraise the impact of accounting information systems in the Bangladeshi banks under the current technological development. By evaluating some standards such as quality, flexibility, simplicity, and reliability. This research endeavor at lifting the competence of these systems and making them more proficient of providing the suitable information to the decision-makers.

Rest of the paper arranged in four parts. part 2 will focus on Literature review; part 3 highlights the objectives of the study; part 4 delineates the data collection methods (primary and Secondary) of the study; part 5 body of the report that includes findings and analysis of using accounting information for strategic decision making in banking sector Bangladesh with a short conclusion in part.6. 


\section{LITERATURE REVIEW}

Information system as a interrelated group of mechanism that collect, receive, process, save, and allocate information to support decision-making and controlling an organization (Laudon, 2012). In addition, it helps managers and workers to look at troubles and create new products. Information technology is known as the electronic resources to assemble, process, store, and broadcast information (Duncombe R, 2007). It is considered as one of the current issues that begin to reflect the significance of using technically processed information to serve several aspects in the society (Avolio et al. 2001) "These technologies led to reducing the in general costs of banking operations" (Jones, 2001). It has become inevitable to distinguish between entities using information technology in their productive and service activities and those still using material systems."Efficient accounting systems should be featured with several characteristics, the most important of which are: system reliability, flexibility and simplicity" (Greenstein and Vasarhelyi, 2002).

The booming expansion of Modern information technology rebellion, accounting environment has been greatly changed, and the conventional accounting information system already cannot satisfy the diversity and individualized needs of enterprise stakeholders (Xiang \& Yin's study, 2011). This paper fulfilled the expectation corporate stakeholders on event accounting approach. It initiates the event vouchers in the financial transaction and operational stuff's competence and accounting information system's seamless docking. Afterward with the "three-base system" as the design ideas, finally assembles the accounting information system based on events approach, accounting information system is finally built up.

Another study scrutinizes the economic basis and justification for profit allocation practices in Islamic financial institutions in Malaysia. Paper describes the categorization on the pool of funds assembles and scrutiny on funds employed were explored in order to form the source in the upholding of shari'ah dictates in the practices of sharing of profit by the practitioners of shari'ahcompliant financial institutions (Yatim, 2009). The outline identified in this study include the principles and fair outlook of financial information, the principle of fairness to mankind and the adoption of fund accounting approach in accounting workouts for income distribution. There emerge proofs of inexcusable application in the course of profit sharing by the practitioners in this sector of economy. As such, this study offers a guide aimed at guarantying the safeguarding the principle of on-going apprehension of the shariah-compliant businesses and financial institutions

Onaolapo and Odetayo (2012) believe that accounting information system has a major effect on organizational success in selected companies in Nigeria. This study inspected the outcome of accounting information system on organizational efficacy specifically on the quality of the financial report and decision-making process. Evocative and inferential statistical tools were used to analyze the data. The results showed accounting information system has an effect on the efficiency of an organization. Financial and project accounting' package software can enhance performance in the finance department.

The benefit of AIS (Accounting Information System) showed how much improvement occurred on the decision-making process, quality of effectiveness of the financial information (Sajady, M.Dastgir and Hashem Nejad, 2008). As soon as the pedals are used appropriately, there will be improved operating effectiveness and efficiency, which will result in enhanced monetary information dependability. Satisfactory accounting information is indispensable for every decision-making method and adequate information is possible if accounting information systems are run efficiently. Well-organized Accounting Information Systems make certain statement that all levels of management obtain enough, ample, applicable and factual information for development and scheming behavior of the business association.

According to Hadi (2014), accounting information helps a company in providing processed information. This processed information helps the management in taking a decision and which has a great impact on organizational profitability. The good information presents better way to take managerial decision and adequate internal control.

Since none of literature are not discussing about the importance of accounting information system on strategic decision making in banking sectors of Bangladesh, this paper endeavors to mitigate the research gap in this regard.

\section{Study ObJectives}

\section{General objective}

The major focus of this study is to analyze the "Importance of accounting information system as strategic decision making tool in banking sector, Bangladesh."

\section{Specific objectives}

- To discover the rate of recurrence of using accounting information system in decision-making in bank zone in Bangladesh.

- To be acquainted with the usefulness of accounting information system in long-term strategic decisions in bank area in Bangladesh.

- To identify the problems faced by accounting information system in the banks, Bangladesh. 


\section{METHODS}

The subsequent method has been followed for conducting this study:

- Sources of Data: The study used primary data collected through opinion survey to evaluate the use of accounting information system in making strategic decisions.

- Sources of Primary Data: Primary data have been collected through a questionnaire survey among the executive level employees of the 40 selected Banks out of total 66 private and public banks in Bangladesh. Moreover, random sampling used for selecting banks.

- Preparation of Questionnaire: The feedback form has been organized based on the appropriate literature of the study. A number of professional views have been in use in preparing the survey.

- The method of Data Collection: Data collected all the way through straight interview method. Therefore, there is a low percentage of failure in collecting data.

- Tools used for Analysis: Statistical Package for the Social Sciences (SPSS) used for data analysis. Furthermore, mean, percentages, standard deviation were used to determine the effectiveness of the accounting information system in long-term strategic decisions.

- Hypotheses of the Study: The following hypotheses tested in the present study:

$\mathrm{H}_{1}$ : There is no connection between Accounting Information system and Basic strategic decisions in Banking Sector, Bangladesh.

$\mathrm{H}_{2}$ : There is no affiliation flanked by Accounting Information system and human resource management decisions in Banking division, Bangladesh.

$\mathrm{H}_{3}$ : There is no association between Accounting Information system and Investment Decisions in Banking segment, Bangladesh.

$\mathrm{H}_{4}$ : There is no connection between Accounting Information system and Marketing Decisions in Banking zone, Bangladesh.

\section{FINDINGS AND ANALYSIS}

\section{a. Demographic information of respondents:}

The result from Table -1 shows that $75 \%$ of total data is collected from the persons who are currently working as senior officer position at different banks. It also shows that $47.5 \%$ are from accounts and finance department from total respondents; $52.5 \%$ of total respondents are working in banks since less than 5 years; $57.5 \%$ of total respondents are holding a MBA degree and $62.5 \%$ of total respondents from age group 30 to 40 .
Table 1: Demographic information of respondents

\begin{tabular}{|c|c|c|c|}
\hline Factors & & Frequency & Percentage \\
\hline \multirow{5}{*}{$\begin{array}{l}\text { 1. Position } \\
\text { of the } \\
\text { Respondent }\end{array}$} & Director & 1 & 2.5 \\
\hline & Manager & 6 & 15 \\
\hline & AGM & 3 & 7.5 \\
\hline & Senior Officer & 30 & 75 \\
\hline & Total & 40 & 100 \\
\hline \multirow{4}{*}{$\begin{array}{l}\text { 2. Name of the } \\
\text { Department }\end{array}$} & Accounts \& Finance & 19 & 47.5 \\
\hline & $\mathrm{Hr}$ and Admin & 6 & 15 \\
\hline & Marketing & 15 & 37.5 \\
\hline & Total & 40 & 100 \\
\hline \multirow{4}{*}{$\begin{array}{l}\text { 3. Duration of } \\
\text { professional } \\
\text { experience } \\
\text { (in Year) } \\
\end{array}$} & Below 5 & 21 & 52.5 \\
\hline & 5 to 10 & 11 & 27.5 \\
\hline & Above 10 & 8 & 20 \\
\hline & Total & 40 & 100 \\
\hline \multirow{5}{*}{$\begin{array}{l}\text { 4. Qualification } \\
\text { in accounting }\end{array}$} & BBA & 12 & 30 \\
\hline & MBA & 23 & 57.5 \\
\hline & CMA & 1 & 2.5 \\
\hline & CA & 4 & 10 \\
\hline & Total & 40 & 100 \\
\hline \multirow{5}{*}{$\begin{array}{l}\text { 5. Age group } \\
\text { of the } \\
\text { respondent }\end{array}$} & Below 30 & 7 & 17.5 \\
\hline & 30 to 40 & 25 & 62.5 \\
\hline & 40 to 50 & 7 & 17.5 \\
\hline & Above 50 & 1 & 2.5 \\
\hline & Total & 40 & 100 \\
\hline
\end{tabular}

Source: own analysis from opinion survey conducted in Jan- Mar 2016

\section{b. Frequency of using accounting information system in Banks:}

Table -2 shows that $72.5 \%$ of the total respondents frequently use accounting information system at their bank, $17.5 \%$ use accounting information system sometimes, and 105 always uses accounting information system at their bank.

Table 2: Frequency of using accounting information system in Banks

\begin{tabular}{|l|l|l|l|l|}
\hline Rarely & Sometimes & Frequently & Always & Never \\
\hline $0(0 \%)$ & $7(17.5 \%)$ & $29(72.5 \%)$ & $4(10 \%)$ & $0(0 \%)$ \\
\hline
\end{tabular}

\begin{tabular}{|l|l|l|l|l|}
\hline $0(0 \%)$ & $7(17.5 \%)$ & $29(72.5 \%)$ & $4(10 \%)$ & $0(0 \%)$ \\
\hline
\end{tabular}

Source: own analysis from opinion survey conducted in Jan- Mar 2016

c. Use of accounting information system in basic strategic decisions:

Table -3 shows that $50 \%$ of total respondent uses accounting information system for making corporate vision related decision that has an arithmetic mean of 1.83 means it is significant and standard deviation of 1.08 also support that. Means accounting information system has a significant affects on making decisions related to corporate vision. It also shows that from the all components of the basic strategic decisions, geographic domain and business unit composition related decision gives a higher arithmetic mean of 2.05 which means it is least accepted and corporate growth related decision gives an arithmetic mean of 1.8 which means it is highly accepted. Table -3 also tells that average arithmetic mean of using accounting information system for making basic strategic decision is 1.9 which is 
significant, means Null hypothesis (H1) is rejected that means accounting information system has a significant relationships with making a basic strategic decisions in banking sector in Bangladesh.

Table 3: Use of accounting information system in Basic Strategic decisions

\begin{tabular}{|c|c|c|c|c|c|c|c|c|}
\hline Variables & $\begin{array}{l}\text { Strongly } \\
\text { agree(1) }\end{array}$ & Agree (2) & $\begin{array}{c}\text { Neutral } \\
\text { (3) }\end{array}$ & $\begin{array}{c}\text { Disagree } \\
(4) \\
\end{array}$ & $\begin{array}{c}\text { Strongly } \\
\text { disagree (5) }\end{array}$ & Total & Mean & SD \\
\hline Corporate vision & $14(35 \%)$ & $20(50 \%)$ & $5(12.5 \%)$ & $1(2.5 \%)$ & $0(0 \%)$ & $40(100 \%)$ & 1.825 & 1.08 \\
\hline Corporate objective & $10(25 \%)$ & $24(60 \%)$ & $6(15 \%)$ & $0(0 \%)$ & $0(0 \%)$ & $40(100 \%)$ & 1.9 & 1.071 \\
\hline Corporate growth strategy & $17(42.5 \%)$ & $15(37.5 \%)$ & $7(17.5 \%)$ & $1(2.5 \%)$ & $0(0 \%)$ & $40(100 \%)$ & 1.8 & 1.085 \\
\hline $\begin{array}{l}\text { Geographic domain and business unit } \\
\text { composition }\end{array}$ & $15(37.5 \%)$ & $11(27.5 \%)$ & $11(27.5 \%)$ & $3(7.5 \%)$ & $0(0 \%)$ & $40(100 \%)$ & 2.05 & 1.095 \\
\hline $\begin{array}{l}\text { Core competence and competitive } \\
\text { advantage }\end{array}$ & $16(40 \%)$ & $13(32.5 \%)$ & $10(25 \%)$ & $1(2.5 \%)$ & $0(0 \%)$ & $40(100 \%)$ & 1.9 & 1.088 \\
\hline
\end{tabular}

Source: own analysis from opinion survey conducted in Jan- Mar 2016

d. Use of accounting information system in human resource management decisions:

Table -4 demonstrate that $70 \%$ of total respondent uses accounting information system for making human resource policy related decision that has an arithmetic mean of 2.25 means it is significant and standard deviation of 1.07 also support that. Means accounting information system has a significant affects on making decisions related to human resource policy. It also shows that from the all variables of the human resource management decisions, promotion, transfer and retrenchment related decision gives a higher arithmetic mean of 2.63, which means it is least accepted, and responsibility determination, performance and reward/punishment related decision gives an arithmetic mean of 2.2, which means it is highly accepted. Table -4 also tells that average arithmetic mean of using accounting information system for making strategic decision is 2.4 which is significant. Null hypothesis (H2) is rejected that means accounting information system has a major relationships with making human resource management decisions in banking sector in Bangladesh.

Table 4: Use of accounting information system in human resource management decisions

\begin{tabular}{|c|c|c|c|c|c|c|c|c|}
\hline Variables & $\begin{array}{l}\text { Strongly } \\
\text { Agree (1) }\end{array}$ & $\begin{array}{c}\text { Agree } \\
\text { (2) }\end{array}$ & $\begin{array}{c}\text { Neutral } \\
\text { (3) }\end{array}$ & $\begin{array}{c}\text { Disagree } \\
(4)\end{array}$ & $\begin{array}{c}\text { Strongly } \\
\text { disagree (5) }\end{array}$ & Total & Mean & SD \\
\hline HR policies & $2(5 \%)$ & $28(70 \%)$ & $8(20 \%)$ & $2(5 \%)$ & $0(0 \%)$ & $40(100 \%)$ & 2.25 & 1.071 \\
\hline Promotion, transfer \& retrenchment & $4(10 \%)$ & $12(30 \%)$ & $20(50 \%)$ & $3(7.5 \%)$ & $1(2.5 \%)$ & $40(100 \%)$ & 2.625 & 1.088 \\
\hline Training \& evelopment & $6(15 \%)$ & $22(55 \%)$ & $10(25 \%)$ & $1(2.5 \%)$ & $1(2.5 \%)$ & $40(100 \%)$ & 2.225 & 1.086 \\
\hline $\begin{array}{l}\text { Organizational culture } \\
\& \text { management style }\end{array}$ & $4(10 \%)$ & $11(27.5 \%)$ & $22(55 \%)$ & $3(7.5 \%)$ & $0(0 \%)$ & $40(100 \%)$ & 2.6 & 1.082 \\
\hline $\begin{array}{l}\text { Responsibility determination, } \\
\text { performance, reward/punishment }\end{array}$ & $6(15 \%)$ & $21(52.5 \%)$ & $12(30 \%)$ & $1(2.5 \%)$ & $0(0 \%)$ & $40(100 \%)$ & 2.2 & 1.078 \\
\hline
\end{tabular}

Source: own analysis from opinion survey conducted in Jan- Mar 2016

e. Use of accounting information system in related decision gives a higher arithmetic mean of 1.87, investment decisions:

Table 5 express that $47.5 \%$ of total respondent uses accounting information system for making a capital raising related decision that has an arithmetic mean of 1.65 means it is significant, and standard deviation of 1.08 also support that. Means accounting information system has a significant effect on making decisions related to capital raise. It also shows that from variables of the investment decisions, investment in fixed asset which means it is least accepted and capital raising related decision gives an arithmetic mean of 1.65 which means it is highly accepted. Table -5 also tells that average arithmetic mean of using accounting information system for making a basic strategic decision is 1.8 which is significant. Null hypothesis (H3) is rejected means accounting information system has a significant relationship with making related investment decisions in the banking sector in Bangladesh.

Table 5: Use of accounting information system in investment decisions

\begin{tabular}{|l|c|c|c|c|c|c|c|c|}
\hline Variables & $\begin{array}{c}\text { Strongly } \\
\text { agree (1) }\end{array}$ & $\begin{array}{c}\text { Agree } \\
\mathbf{( 2 )}\end{array}$ & $\begin{array}{c}\text { Neutral } \\
\mathbf{( 3 )}\end{array}$ & $\begin{array}{c}\text { Disagree } \\
\mathbf{( 4 )}\end{array}$ & $\begin{array}{c}\text { Strongly } \\
\text { Disagree (5) }\end{array}$ & Total & Mean & SD \\
\hline Capital raising & $19(47.5 \%)$ & $16(40 \%)$ & $5(12.5 \%)$ & $0(0 \%)$ & $0(0 \%)$ & $40(100 \%)$ & 1.65 & 1.077 \\
\hline Borrowings & $18(45 \%)$ & $14(35 \%)$ & $8(20 \%)$ & $0(0 \%)$ & $0(0 \%)$ & $40(100 \%)$ & 1.75 & 1.082 \\
\hline Liquidation & $14(35 \%)$ & $19(47.5 \%)$ & $7(17.5 \%)$ & $0(0 \%)$ & $0(0 \%)$ & $40(100 \%)$ & 1.825 & 1.077 \\
\hline Dividend payout & $16(40 \%)$ & $17(42.5 \%)$ & $7(17.5 \%)$ & $0(0 \%)$ & $0(0 \%)$ & $40(100 \%)$ & 1.775 & 1.079 \\
\hline Investment in fixed assets & $12(30 \%)$ & $21(52.5 \%)$ & $7(17.5 \%)$ & $0(0 \%)$ & $0(0 \%)$ & $40(100 \%)$ & 1.875 & 1.075 \\
\hline
\end{tabular}

Source: own analysis from opinion survey conducted in Jan- Mar 2016 


\section{f. Use of accounting information system in} marketing decisions:

Table -6 shows that $52.5 \%$ of total respondent uses accounting information system for making decision related to selling and marketing strategy that has an arithmetic mean of 2.02 means it is significant and standard deviation of 1.07 also support that. Means accounting information system has a significant affects on making decisions related to selling and marketing strategy. It also shows that from the all variables of the marketing decisions, marketing research related decision gives a higher arithmetic mean of 2.25 , which means it is least accepted and sales commission related decision gives an arithmetic mean of 1.97 which means it is highly accepted. Table -6 also tells that average arithmetic mean of using accounting information system for making strategic decision is 2.12 which is significant. Null hypothesis (H4) is rejected that means accounting information system has a important relationship with making marketing related decisions in banking sector in Bangladesh.

Table 6: Use of accounting information system in marketing decisions

\begin{tabular}{|l|c|c|c|c|c|c|c|c|}
\hline Variables & $\begin{array}{l}\text { Strongly } \\
\text { agree (1) }\end{array}$ & Agree (2) & Neutral (3) & Disagree (4) & $\begin{array}{c}\text { Strongly } \\
\text { Disagree (5) }\end{array}$ & Total & Mean & SD \\
\hline Selling and marketing strategy & $9(22.5 \%)$ & $21(52.5 \%)$ & $10(25 \%)$ & $0(0 \%)$ & $0(0 \%)$ & $40(100 \%)$ & 2.025 & 1.076 \\
\hline Promotional policies & $7(17.5 \%)$ & $20(50 \%)$ & $13(32.5 \%)$ & $0(0 \%)$ & $0(0 \%)$ & $40(100 \%)$ & 2.15 & 1.077 \\
\hline Market segmentation & $12(30 \%)$ & $14(35 \%)$ & $8(20 \%)$ & $6(15 \%)$ & $0(0 \%)$ & $40(100 \%)$ & 2.2 & 1.098 \\
\hline Sales commission & $11(27.5 \%)$ & $19(47.5 \%)$ & $10(25 \%)$ & $0(0 \%)$ & $0(0 \%)$ & $40(100 \%)$ & 1.975 & 1.079 \\
\hline Marketing research & $6(15 \%)$ & $22(55 \%)$ & $8(20 \%)$ & $4(10 \%)$ & $0(0 \%)$ & $40(100 \%)$ & 2.25 & 1.086 \\
\hline
\end{tabular}

Source: own analysis from opinion survey conducted in Jan- Mar 2016

g. Problems of accounting information system in the banks: Table-7 demonstrates the problems of using accounting information system in the banks. It is found from the own analysis of the table- 7 that $60 \%$ of the total respondents says accounting information system uses new technology/techniques/approaches of accounting, $60 \%$ disagrees with the statement of that accounting information system has no involvement of higher authority in strategic decision making. Analysis also shows that $40 \%$ of total respondents say they do have skill personnel to work with accounting information system but other $40 \%$ respondents from rest Respondent remained silent to talk about this issue. It also tells that $47.5 \%$ of total respondents says they do have sufficient IT infrastructure to use accounting information system in their banks, therefore IT requirements for using accounting information system is not really seems to be a problem for their banks.

Table 7: Problems of using accounting information system in the Banking sector in Bangladesh

\begin{tabular}{|l|c|c|c|c|c|c|}
\hline Variables & $\begin{array}{c}\text { Strongly } \\
\text { Agree (1) }\end{array}$ & Agree (2) & Neutral (3) & Disagree (4) & $\begin{array}{c}\text { Strongly } \\
\text { Disagree (5) }\end{array}$ & Total \\
\hline $\begin{array}{l}\text { Do not use modern } \\
\text { techniques/approach of accounting }\end{array}$ & $0(0 \%)$ & $1(2.5 \%)$ & $9(22.5 \%)$ & $24(60 \%)$ & $6(15 \%)$ & $\begin{array}{c}40 \\
(100 \%)\end{array}$ \\
\hline $\begin{array}{l}\text { No involvement of higher authority } \\
\text { in strategic decision making }\end{array}$ & $0(0 \%)$ & $0(0 \%)$ & $10(25 \%)$ & $24(60 \%)$ & $5(15 \%)$ & $\begin{array}{c}40 \\
(100 \%)\end{array}$ \\
\hline Staffs are unqualified for AIS & $1(2.5 \%)$ & $0(0 \%)$ & $16(40 \%)$ & $16(40 \%)$ & $7(17.5 \%)$ & $\begin{array}{c}40 \\
(100 \%)\end{array}$ \\
\hline $\begin{array}{l}\text { Do not keep pace with IT } \\
\text { requirements }\end{array}$ & $0(0 \%)$ & $0(0 \%)$ & $16(40 \%)$ & $19(47.5 \%)$ & $5(12.5 \%)$ & $\begin{array}{c}40 \\
(100 \%)\end{array}$ \\
\hline
\end{tabular}

Source: own analysis from opinion survey conducted in Jan- Mar 2016

The following are the summary of the study-

- Form the opinion analysis it has proved that accounting information system has a significant relationship with all the components of strategic decision making in the banking sector in Bangladesh.

- It is visible from the opinion analysis that $72.5 \%$ of total respondents are using accounting system frequently for making strategic decisions for different components of their banks whereas $17.5 \%$ says they use it sometimes, and $10 \%$ of total respondents use the system always for making strategic decisions. As major portion of our banking zone uses accounting information system, I do believe that the research outcomes will be strongly applicable in the context of Bangladeshi Banks.
- After analyzing the use of accounting information system in the basic strategic decisions, it has been found that highest $60 \%$ of total respondent says they agree with the corporate objective related decisions which shows a significant relationship with basic strategic decisions while using accounting information system.

- The analysis of using accounting information system in human resource management decision making revealed that $70 \%$ of total respondents says it has a significant effect on human resource policy related decisions.

- Analysis of using accounting information system in investment decision making shows that major percentage of the total respondents talks about all the variables are significantly affected by the use of accounting information system. 
- The analysis also shows the same result for marketing related decisions where most of the respondents say accounting information system has a significant relationship with marketing related decisions.

- This opinion analysis found that there is no major problem of using accounting information system in banks and this system comply with current IT infrastructure of the banks of Bangladesh.

\section{CONCLUSION}

The study revealed that accounting information system plays a crucial role in strategic decision making in Banking sector in Bangladesh by not just looking at the ease way taking decisions but also considering accuracy, effectiveness and efficiency of taking decisions for the banks. It also found that how many percentages are using this accounting information system for strategic decisionmaking purpose. This study also tried to discover the major problems faced by the banks while using this accounting information system in the purpose of decisionmaking. This study will be helpful for those banks that are planning to implement an accounting information system into their bank for strategic decision-making purpose.

There were some limitations too of the study as the study only focused on the banking sector of Bangladesh. And also, I had to face some hard time to collect data as the respondent were too busy with their work and I thought time was not enough to collect the data from the respondents.

As this study, only deal with the use of accounting information system in the banking sector in Bangladesh so there can be some other research work in the future focusing on the use of accounting information system in NGO's in Bangladesh. The impact of accounting information system in financial performance evaluation in Bangladesh could be another area of research work in the future.

\section{REFERENCES}

Avolio, B. J., Kahai, S. S., \& Dodge, G. E. (2001) 'E-leadership: Implications for theory, research, and practice', Leadership Quarterly, vol. 11, pp. 615-668.

Daw Hla And Susan Peter Teru (2015) 'Efficiency of Accounting Information System and Performance Measures Literature Review ', International Journal of Multidisciplinary and Current Research, vol.3, pp. 976-984.
Duncombe, Rechard (2007) 'Using the livelihood framework to analyze ICT applications for poverty reduction through microenterprise', Information technologies and international development, vol. 3, no. 3, pp. 81-100.

Eugenia1, I and Tiberiu, S. (2013) 'Accounting Information for Strategic Decisions', Educational Research International, vol. 1, no. 1, pp. 92-93.

Goodwin-Jones, B. (2001) 'Emerging technologies - accessibility and web design why does it matter?', Language Learning and Technology, vol. 5, pp. 11-19.

Greenstain and Vasarhelyi (2002) Electronic Commerce: Security, risk management, and control, 2nd edn., New York: McGraw-Hill- Irwin.

H. Sajady, M. Dastgir and Hashemnejad (2008) 'Evaluation of the effectiveness of accounting information systems', International Journal of Information Science $\mathcal{E}$ Technology, vol.6, no.2

Hadi Saeidi (2014) 'The impact of accounting information systems on financial performance -a case study of TCS India', Indian Journal of Fundamental and Applied Life Sciences, vol.4, no. 4, pp. 412-417.

Kenneth C. Laudon and Jane P. Laudon (2012) Managing The Digital Firm, 12th edn., New Jersey: Prentice Hall.

Marshall B. Romney, Paul John Steinbart (2014) Accounting Information System, 13th edn., New York: Pearson.

Onaolapo, A. A., \& Odetayo, T. A. (2012) 'Effect of Accounting Information System on Organizational Effectiveness: A Case Study of Selected Construction Companies in Ibadan, Nigeria', American Journal of Business and Management, vol.1, no.4, pp. 183-189.

Royaee, R., Salehi, A., and Aseman, H. S (2012) 'Does Accounting Play A Significant Role In Managerial Decision-Making? ', Research Journal of Business Management and Accounting, vol. 1, no. 4, pp. 57-63.

Trimisiu Tunji (2012) 'Accounting Information As An Aid To Management Decision Making', International Journal of Management and Social Sciences Research, vol. 1, no 3, pp. 29-30

Ullah Md. Hafiz, Jamil Ahmed Khonadakar \& Syeda Tamanna Fahim (2014) 'Role of Accounting Information in Strategic Decision Making in Manufacturing Industries in Bangladesh', Global Journals Inc. (USA), vol.14, no. 1, pp. 9-22.

Xiang, Hu., Yin, Kong. (2011) ' Research on the construction of accounting information based on events approach,' American Journal of Engineering and Technology Research, vol.11, no.9, pp. 154-169.

Yatim, M. (2009) 'Accounting Information System for Profit Distribution of Islamic Financial Institution', African Journal of Business Management, vol.3, no.11, pp. 773-780.

$$
--0--
$$

Indexed Archive Links

OCLC WorldCat: http://goo.gl/vhQzla

Google Scholar: https://goo.gl/t23FeQ

abcGATE: http://goo.gl/E6WdgA

BASE: http://goo.gl/sEd0SZ

\section{5) WorldCat' Google scholar}

